\title{
KOMBINASI MINYAK IKAN SARDIN DAN CUCUT KAYA OMEGA-3 DAN SQUALENE
}

\section{Combination of Sardine and Shark Oil High Content of Omega-3 and Squalene}

\author{
Muhamad Musbah*, Sugeng Heri Suseno, Uju \\ Departemen Teknologi Hasil Perairan, Fakultas Perikanan dan Ilmu Kelautan, \\ Institut Pertanian Bogor, Kampus IPB Dramaga, Jalan Agatis, Bogor 16680 Jawa Barat \\ Telepon (0251) 8622909-8622906, faks (0251) 8622915. \\ *Korespodensi: muhamad_musbah@yahoo.com \\ Diterima: 25 Januari 2017/ Disetujui: 18 April 2017
}

Cara sitasi: Musbah M, Suseno SH, Uju. Kombinasi minyak ikan sardin dan cucut kaya omega-3 dan squalene. Jurnal Pengolahan Hasil Perikanan Indonesia. 20(1): 45-52.

\begin{abstract}
Abstrak
Minyak ikan sardin memiliki kandungan EPA yang cukup tinggi jika dibandingkan dengan kandungan DHA. Kandungan tersebut berbanding terbalik pada minyak ikan cucut yaitu DHA dan squalene merupakan komponen yang tinggi namun rendah EPA. Kandungan EPA, DHA dan squalene dalam minyak ikan sangat bermanfaat dalam bidang farmasi. Penelitian ini bertujuan untuk memperkaya minyak ikan dengan omega-3 dan squalene serta meningkatkan kualitasnya. Kombinasi minyak ikan (sardin:cucut) 1:1, 1:2, 1:3, 1:4, 2:1, 3:1 dan 4:1 memberikan hasil yang berbeda sangat nyata terhadap kandungan bilangan peroksida, bilangan anisidin dan total oksidasi, tetapi tidak berbeda nyata untuk uji asam lemak bebas. Parameter oksidasi terbaik dihasilkan dari rasio pencampuran (sardin:cucut) 1:4 dengan nilai peroksida 5,44 $\pm 0,06 \mathrm{mEq} / \mathrm{kg}$, bilangan anisidin $8,3 \pm 0,72 \mathrm{mEq} / \mathrm{kg}$ dan total oksidasi $19,27 \pm 0,7 \mathrm{mEq} / \mathrm{kg}$. Profil asam lemak kombinasi minyak sardin dan cucut memberikan variasi kandungan terhadap SFA, MUFA dan PUFA. Minyak sardin semakin banyak ditambahkan pada rasio kombinasi akan menghasilkan kandungan omega-3 yang semakin tinggi. Sampel 1:4 menunjukkan kandungan squalene 43,16\%.
\end{abstract}

Kata kunci: asam dekosaheksaenoat, asam eikosapentaenoat, oksidasi

\section{Abstract}

Sardine oil contain high concentration of EPA but low of DHA while shark is reverse. Shark oil high contain of DHA and squalene but low EPA. This research aim to fortify the quality of fish oil withomega-3 and squalen and improve the quality of fish oil. The combination of fish oil (sardine:shark) 1: 1, 1: 2, 1: 3, 1: 4, 2: 1, 3: 1 and 4:1 showed significant results on peroxide, anisidine, and total oxidation value, however free fatty acids analysis did not show the influence to the content value. The best oxidation parameters value werefound (sardine: shark) (1:4) with peroxide was $5.44 \pm 0.06 \mathrm{mEq} / \mathrm{kg}$, anisidine was $8.3 \pm 0.72 \mathrm{mEq} / \mathrm{kg}$ and total oxidation was $19.27 \pm 0.7 \mathrm{mEq} / \mathrm{kg}$. Fatty acids profile between sardines and shark oil containedvarious SFA, MUFA and PUFA. Sardine oil which was added more to combination ratio will increase omega-3. Sample 1:4 had $43.16 \%$ squalene.

Keywords: eicosapentaenoic acid (EPA), decosahexaenoic acid (DHA), oxidation

\section{PENDAHULUAN}

Asam lemak tidak jenuh merupakan komponen esensial bagi tubuh manusia, terutama asam lemak rantai panjang Eicosapentanoic acid/EPA dan dokosaheksanoic acid/DHA yang banyak ditemukan pada minyak ikan (Loef dan Walach 2013). Minyak ikan sardin adalah produk hasil samping pengalengan yang mengandung omega-3 cukup tinggi yaitu EPA 15,54\% dan DHA 6,41\% (Suseno et al. 2013 ${ }^{\mathrm{a}}$ ). Minyak ikan sardin sebagai bahan baku produk minyak ikan memiliki kekurangan yaitu kandungan DHA yang rendah jika bandingkan dengan kandungan DHA pada minyak ikan cucut. Minyak ikan cucut 
(Centrophorus squamosus) mengandung DHA 25,05\% dan rendah EPA 5,14\% (Garcia et al. 2000). Minyak ikan cucut juga mengandung squalene $83 \%$, vitamin A dan D yang sangat baik bagi kesehatan (Wetherbe 2000).

Squalene memiliki fungsi yang sangat penting bagi tubuh manusia, yaitu untuk penguat stamina tubuh, menyembuhkan penyakit liver, kencing manis dan mencegah penyakit degeneratif (Kelly 1999). EPA dan DHA memiliki peranan penting yaitu untuk perkembangan otak, retina mata, peningkatan kekebalan, pencegahan penyakit degenaratif, membantu dalam pengembangan kejiwaan, pertumbuhan anak-anak usia dini, terutama bagi anak-anak penderita autism spectrum disorders (Schuchardt 2010; Baken et al. 2014).

Manfaat minyak ikan yang besar terhadap kesehatan manusiamendorongpengembangan inovasi produk minyak ikan dalam bentuk pangan fungsional atau pharmaceutical terus meningkat. Penelitian pengembangan kualitas minyak ikan yang telah dilakukan yaitu: karakteristik dan kestabilan kombinasi minyak ikan sardin dengan habbatussauda Suseno et al. $\left(2013^{\mathrm{b}}\right)$, peningkatan kualitas minyak ikan dengan metode Degumming menggunakan asam sitrat dan garam hingga memenuhi standar pangan (Suseno et al. 2016), kombinasi minyak ikan patin dan minyak sawit merah yang diaplikasikan ke bubur instan dan cookies (Dewita et al. 2015), kombinasi minyak ikan jambal dan kerapu untuk memenuhi standar rasio omega-3 dan omega-6 yang baik menurut WHO (Ilza dan Siregar 2015).

Kombinasi minyak ikan sardin dan cucut sejauh ini belum pernah dilakukan. Penelitian ini diharapkan dapat menghasilkan minyak ikan yang mengandung asam lemak kaya omega-3 dan squalene serta rendah oksidasi yang dapat diaplikasikan dalam bidang pangan dan farmasi. Penelitian ini bertujuan untuk memperkaya minyak ikan dengan omega-3 dan squalene serta meningkatkan kualitas kombinasi minyak sardin dan cucut.

\section{BAHAN DAN METODE Bahan dan Alat}

Penelitian ini menggunakan bahan yang meliputi minyak sardin hasil samping industri penepungan dan minyak cucut hasil produk industri Rumah Tangga Pelabuhan Ratu. Bahan-bahan kimia yang digunakan meliputi $\mathrm{KOH}$ (Merck), $\mathrm{CH}_{3} \mathrm{COOH}$ (Merck), kloroform (Merck), $\mathrm{Na}_{2} \mathrm{SO}_{3}$ (Merck), trimethylpentane (Merck), larutan p-Anisidin (Sigma Aldrich), magnesol XL dan asam sitrat. Alat yang digunakan yaitu burret (Iwaki Pyrex), spektrofotometer UV-VIS (Agilent 8453), timbangan digital (Quattro) dan mikropipet (Axygen), perangkat kromatografi gas (SHIMADZU GC2010), GC-MS (Agilent 7890A).

\section{Metode Penelitian}

Proses pemurnian dilakukan terhadap minyak sardin dan cucut dengan tahapan Degumming (penghilangan gum), neutralization (netralisasi/penyabunan), dan bleaching (pemucatan) kemudian dikombinasikan. Degumming dilakukan dengan cara memanaskan $100 \mathrm{~g}$ minyak ikan pada suhu $50^{\circ} \mathrm{C}$ dan kecepatan stirer $800 \mathrm{rpm}$, setelah mencapai suhu tersebut ditambahkan $2 \mathrm{~mL}$ akuades, dipanaskan selama 10 menit, kemudian ditambahkan asam sitrat 0,4\% (b/v). Netralisasi dengan cara menambahkan $\mathrm{NaOH} 18^{\circ} \mathrm{Be}$ pada suhu $50^{\circ} \mathrm{C}$, kecepatan stirer $800 \mathrm{rpm}$ selama 20 menit, dan pemisahan endapan dilakukan dengan sentrifugasi pada 108 g selama 10 menit. Fraksi supernatan (minyak) dipanaskan hingga suhu $50^{\circ} \mathrm{C}$ pada kecepatan stirer $800 \mathrm{rpm}$ kemudian ditambah Magnesol XL 5\% selama 20 menit (proses bleaching). Magnesol XL dan minyak ikan dipisahkan dengan sentrifugasi pada $108 \mathrm{~g}$ selama 10 menit.

Minyakikanhasil pemurnian dikombinasi dengan perbandingan sardin:cucut yaitu 1:1, 1:2, 1:3, 1:4, 2:1, 3:1, dan 4:1 kemudian dianalisis parameter oksidasi primer dan sekundernya. Minyak hasil kombinasi (1:4) memiliki parameter oksidasi terbaik sehingga dilanjutkan dengan analisis kandungan 
Squalene. Analisis data hasil penelitian pada profil asam lemak dan kandungan Squalene dilakukan secara deskriptif, dan analisis parameter oksidasi menggunakan Rancangan Acak Lengkap (RAL) dengan tiga kali ulangan.

Prosedur analisis yang dilakukan meliputi analisis asam lemak bebas (FFA) berdasarkan AOCS (1998) Ca-5a-40. Analisis bilangan peroksida (PV) dengan metode AOCS (1995) Cd-8b-90. Penentuan nilai anisidin (p-AV) menggunakan metode Watson (1994). Penentuan nilai total oksidasi (TOTOX) menggunakan metode Perrin (1996). Penentuan profil asam lemak dengan metode AOAC (2005) No. Metode 969.33.

\section{Analisis kandungan squalene}

Analisis kandungan Squalene pada minyak kombinasi sardin dan cucut dilakukan dengan GC-MS (Agilent 7890A/5975C MDS) menggunakan kolom Agilent 19091J-413HP-5 5\% Diphenyl dan 95\% Methyl Poli Siloxan, $60 \mathrm{~m} \times 250 \mu \mathrm{m} \times 0,25 \mu \mathrm{m}$. Suhu yang digunakan pada $100^{\circ} \mathrm{C}$ selama 5 menit, kemudian meningkat $15^{\circ} \mathrm{C} /$ menit sampai suhu $280^{\circ} \mathrm{C}$ dan selama 22 menit. Injeksi split menggunakan rasio split 5:1 dengan volume injeksi $1 \mu \mathrm{L}$. Spektrum massa yang diperoleh lalu dibandingkan dengan Library Willey9 N11.L.

\section{HASIL DAN PEMBAHASAN Kadar asam lemak bebas (ALB)}

Asam lemak bebas merupakan asam lemak yang terbentuk karena proses hidrolisis dan oksidasi (Suseno et al. 2014). Kadar asam lemak bebas minyak sardin dan cucut masingmasing $0,52 \%$ dan $0,53 \%$ (Tabel 1).

Asam lemak bebas minyak sardin dan cucut setelah dikombinasi (1:1,1:2, 1:3, 1:4, 2:1, 3:1,dan 4:1) menunjukkan nilai yang berbeda tidak nyata $(p>0,05)$. Hasil inidisebabkan oleh nilai ALB awal pada minyak sardin dan cucut yang sudah sangat rendah. Nilai ALB hasil kombinasi untuk semua perlakuan memenuhi standar International Fish Oil Standard (IFOS 2014) yaitu 1,50\%. Gunawan et al. (2003) menjelaskan bahwa enzim lipase pada minyak dapat menghidrolisis trigliserida sehingga menghasilkan asam lemak bebas dan gliserol. Reaksi pembentukan asam lemak bebas dipercepat dengan adanya panas, air, asam dan katalis enzim. Asam lemak bebas yang terbentuk akan meningkat jika proses tersebut semakin lama berlangsung (Hernandez dan Kamal-Eldin 2013).

\section{Bilangan peroksida (PV)}

Kombinasi minyak ikan sardin dan cucut $(1: 1,1: 2,1: 3,1: 4,2: 1,3: 1$ dan 4:1) memberikan pengaruh berbeda sangat nyata $(p<0,05)$ terhadap nilai peroksida. Kombinasi minyak ikan (sardin:cucut) yang didominasi minyak cucut (1:4) menghasilkan nilai peroksida terendah yaitu $5,4 \pm 0,06 \mathrm{mEq} /$ $\mathrm{kg}$, sebaliknya dengan penambahan minyak cucut sedikit atau penambahan minyak ikan sardin yang lebih besar (4:1) menghasilkan nilai peroksida yang semakin tinggi yaitu $11,6 \mathrm{mEq} / \mathrm{kg}$. Nilai peroksida yang menurun dengan penambahan minyak cucut yang semakin besar diduga karena minyak cucut mengandung vitamin A dan Squalene yang dapat berfungsi sebagai antioksidan alami. Kohno et al. (1995) menjelaskan bahwa Squalene stabil terhadap serangan radikal peroksida. Nilai peroksida yang tinggi dengan penambahan minyak sardin yang semakin banyak diduga karena minyak sardin sebelum dikombinasi mengalami kontak langsung dengan udara dan penggunaan suhu tinggi pada saat ekstraksi sehingga ikatan rangkap terputus dan ikatan rangkap mengikat oksigen mengakibatkan meningkatnya peroksida. Aidos et al. (2003) menjelaskan bahwa nilai peroksida sangat dipengaruhi oleh suhu ekstraksi minyak, semakin tinggi suhu yang digunakan makan semakin tinggi nilai peroksida minyak tersebut.

\section{Nilai anisidin (p-AV)}

Nilai anisidin adalah parameter oksidasi minyak yang mengukur oksidasi sekunder dari hasil degradasi lemak atau minyak yang diinisiasi oleh hidroperoksida sehingga menghasilkan produk karbonil yang bersifat non-volatile (Aidos et al. 2002). Nilai anisidin sangat erat kaitannya dengan bilangan peroksida pada minyak sardin dan cucut awal sebelum dikombinasi. Bilangan peroksida yang tinggi pada minyak ikan akan terdekomposisi menghasilkan berbagai senyawa terutama 
Tabel 1 Nilai asam lemak bebas (ALB), peroksida (PV), Anisidin (p-AV) dan Total Oksidasi (TOTOX) kombinasi minyak ikan sardin dan cucut

\begin{tabular}{lcccc}
\hline \multicolumn{1}{c}{ Sampel } & FFA & PV & AnV & TOTOX \\
\hline Sardin & $0,52 \pm 0,08^{\mathrm{a}}$ & $12,0 \pm 0,48^{\mathrm{g}}$ & $32,9 \pm 0,45^{\mathrm{f}}$ & $56,9 \pm 0,75^{\mathrm{i}}$ \\
Cucut & $0,53 \pm 0,01^{\mathrm{a}}$ & $4,5 \pm 0,21^{\mathrm{a}}$ & $7,3 \pm 0,89^{\mathrm{a}}$ & $16,3 \pm 0,84^{\mathrm{a}}$ \\
(sardin:cucut/1:1) & $0,53 \pm 0,05^{\mathrm{a}}$ & $9,8 \pm 0,71^{\mathrm{e}}$ & $14,1 \pm 0,60^{\mathrm{c}}$ & $33,8 \pm 1,43^{\mathrm{e}}$ \\
(sardin:cucut/1:2) & $0,50 \pm 0,07^{\mathrm{a}}$ & $8,8 \pm 0,64^{\mathrm{d}}$ & $12,1 \pm 1,66^{\mathrm{b}}$ & $29,6 \pm 0,58^{\mathrm{d}}$ \\
(sardin:cucut/1:3) & $0,52 \pm 0,08^{\mathrm{a}}$ & $6,2 \pm 0,06^{\mathrm{c}}$ & $11,4 \pm 0,06^{\mathrm{b}}$ & $23,8 \pm 0,16^{\mathrm{c}}$ \\
(sardin:cucut/1:4) & $0,53 \pm 0,05^{\mathrm{a}}$ & $5,4 \pm 0,06^{\mathrm{b}}$ & $8,3 \pm 0,72^{\mathrm{a}}$ & $19,2 \pm 0,70^{\mathrm{b}}$ \\
(sardin:cucut/2:1) & $0,53 \pm 0,09^{\mathrm{a}}$ & $10,3 \pm 0,28^{\mathrm{e}}$ & $19,2 \pm 0,07^{\mathrm{d}}$ & $39,8 \pm 0,48^{\mathrm{f}}$ \\
(sardin:cucut/3:1) & $0,52 \pm 0,01^{\mathrm{a}}$ & $11,0 \pm 0,22^{\mathrm{f}}$ & $30,5 \pm 0,80^{\mathrm{e}}$ & $52,6 \pm 0,43^{\mathrm{g}}$ \\
(sardin:cucut/4:1) & $0,52 \pm 0,01^{\mathrm{a}}$ & $11,6 \pm 0,07^{\mathrm{fg}}$ & $31,3 \pm 1,06^{\mathrm{e}}$ & $54,5 \pm 1,21^{\mathrm{h}}$ \\
\hline IFOS & $\leq 1,50$ & $\leq 5,0$ & $\leq 20,0$ & $\leq 26,0$ \\
\hline
\end{tabular}

Keterangan: Huruf yang sama menunjukkan tidak berbeda nyata $(p<0,05)$ dan huruf yang berbeda menunjukan perbedaan yang nyata $(p>0,05)$

golongan aldehid, jumlah akumulasi aldehid dinyatakan sebagai bilangan anisidin (Ketaren 2012).

Tabel 1 menunjukkan nilai anisidin kombinasi minyak ikan sardin dan cucut (1:1, $1: 2,1: 3,1: 4,2: 1,3: 1$ dan 4:1) memberikan nilai yang berbeda sangat nyata $(p<0,05)$. Nilai anisidin terendah diperoleh dengan penambahan minyak ikan cucut terbanyak yaitu pada rasio $1: 4$ (sardin:cucut) $8,3 \pm 0,72$ $\mathrm{mEq} / \mathrm{kg}$, sedangkan nilai tertinggi ditemukan pada panambahan minyak ikan sardin yang semakin banyak yaitu pada rasio 4:1 (sardin:cucut) $\quad 31,3 \pm 1,06 \quad \mathrm{mEq} / \mathrm{kg}$. Nilai anisidin kombinasi minyak (sardin:cucut) yang memenuhi standar IFOS $\leq 20.00$ yaitu $2: 1(19,2 \pm 0,07 \mathrm{mEq} / \mathrm{kg}), 1: 1(14,1 \pm 0,60 \mathrm{mEq} /$ $\mathrm{kg}), 1: 2(12,1 \pm 1,66 \mathrm{mEq} / \mathrm{kg}), 1: 3(11,4 \pm 0,06$ $\mathrm{mEq} / \mathrm{kg})$ dan $1: 4(8,3 \pm 0,72 \mathrm{mEq} / \mathrm{kg})$.

\section{Bilangan total oksidasi (TOTOX)}

Total oksidasi adalah penggabungan dua kali nilai bilangan peroksida dan satu bilangan anisidin. Tabel 1 menunjukkan nilai total oksidasi kombinasi minyak ikan sardin dan cucut $(1: 1,1: 2,1: 3,1: 4,2: 1,3: 1$ dan 4:1) memberikan nilai yang berbeda sangat nyata $(p<0,05)$. Penambahan minyak cucut yang semakin banyak (1:2, 1:3 dan 1:4) menghasilkan total oksidasi yang semakin rendah, sedangkan dengan penambahan minyak sardin semakin banyak $(2: 1,3: 1$ dan 4:1) menghasilkan total oksidasi yang semakin tinggi. Total oksidasi kombinasi minyak (sardin:cucut) yang terbaik dan memenuhi standar IFOS (2014) $\leq 26,00$ $\mathrm{mEq} / \mathrm{kg}$ ditemukan pada rasio 1:4 yaitu $19,2 \pm 0,07 \mathrm{mEq} / \mathrm{kg}$. Kombinasi minyak ikan (sardin:cucut) yang tidak memenuhi standar total oksidasi IFOS (2014) diduga karena nilai bilangan peroksida dan anisidin yang tinggi sebelum dikombinasi sehingga memberikan pengaruh terhadap tingginya nilai total oksidasi. Bimbo (1998) total oksidasi minyak $10-60 \mathrm{mEq} / \mathrm{kg}$ masih layak untuk dikonsumsi.

\section{Profil asam lemak}

Profil asam lemak hasil analisis GC dari kombinasi minyak (sardin:cucut) menunjukkan bahwa dengan penambahan minyak sardin lebih besar (4:1) menghasilkan nilai Saturated Fatty Acid (SFA) yang lebih tinggi dari semua perlakuan kombinasi yaitu 26,11\% serta PUFA mengalami peningkatan yaitu 19,95\%. Penambahan minyak cucut semakin banyak pada rasio kombinasi (1:4) menghasilkan nilai Mono UnSaturated Fatty Acid (MUFA) yang lebih tinggi yaitu 37,87\%. Total jumlah asam lemak omega-3 minyak sardin 20,45\%, cucut $6,13 \%$, kombinasi (1:1) 14,03\%; (1:2) 9,27\%; (1:3) 8,83\%; (1:4) 8,55\%; (2:1) 9,29\%; (3:1) $16,18 \%$ dan (4:1) $16,58 \%$. Minyak sardin yang ditambahkan pada minyak ikan cucut semakin tinggi maka 
Tabel 2 Profil asam lemak kombinasi minyak ikan sardin dan cucut

\begin{tabular}{|c|c|c|c|c|c|c|c|c|c|c|}
\hline \multirow{2}{*}{ Asam Lemak/Fatty Acid } & \multirow{2}{*}{$\%(w / w)$} & \multirow{2}{*}{ Sardin } & \multirow{2}{*}{ Cucut } & \multicolumn{7}{|c|}{ Rasio Kombinasi Minyak (Sardin:Cucut)/w/w } \\
\hline & & & & $(1: 1)$ & $(1: 2)$ & $(1: 3)$ & $(1: 4)$ & $(2: 1)$ & $(3: 1)$ & $(4: 1)$ \\
\hline Asam laurat & $\mathrm{C} 12: 0$ & 0,14 & 0,02 & 0,05 & 0,03 & 0,02 & 0,03 & 0,03 & 0,05 & 0,06 \\
\hline Asam miristat & C14:0 & 13,37 & 0,82 & 5,86 & 2,58 & 2,33 & 1,94 & 2,76 & 7,76 & 7,63 \\
\hline Asam pentadekanoat & $\mathrm{C} 15: 0$ & 0,14 & 0,18 & 0,32 & 0,23 & 0,21 & 0,24 & 0,22 & 0,37 & 0,37 \\
\hline Asam palmitat & C16:0 & 22,54 & 12,04 & 14,0 & 13,07 & 13,22 & 13,89 & 12,84 & 13,32 & 14,19 \\
\hline Asam heptadekanoat & C17:0 & $\operatorname{ttd}$ & 0,33 & 0,40 & 0,34 & 0,33 & 0,38 & 0,34 & 0,40 & 0,43 \\
\hline Asam stearat & C18:0 & 1,50 & 4,07 & 3,08 & 3,55 & 3,78 & 4,14 & 3,56 & 2,59 & 2,84 \\
\hline Asam arakidat & C20:0 & 0,13 & 0,26 & 0,25 & 0,25 & 0,25 & 0,30 & 0,25 & 0,24 & 0,27 \\
\hline Asam heneikosanoat & C21:0 & 0,02 & 0,03 & 0,08 & 0,02 & 0,03 & 0,03 & 0,05 & 0,07 & 0,07 \\
\hline Asam behenat & $\mathrm{C} 22: 0$ & 0,04 & 0,13 & 0,14 & 0,13 & 0,13 & 0,14 & 0,12 & 0,14 & 0,15 \\
\hline Asam Tricoanoic & C23:0 & 0,03 & 0,02 & 0,02 & 0,03 & 0,02 & 0,03 & 0,02 & 0,02 & 0,02 \\
\hline Asam lignoserat & $\mathrm{C} 24: 0$ & 0,03 & 0,06 & 0,06 & 0,06 & 0,06 & 0,07 & 0,06 & 0,06 & 0,08 \\
\hline Total SFA & & 37,94 & 17,96 & 24,26 & 20,29 & 20,38 & 21,19 & 20,25 & 25,02 & 26,11 \\
\hline Asam miristoleat & $\mathrm{C} 14: 1$ & 0,04 & 0,06 & 0,04 & 0,05 & 0,05 & 0,06 & 0,04 & 0,03 & 0,03 \\
\hline Asam cis-10-Pentadecanoad & $\mathrm{C} 15: 1$ & 0,02 & $\operatorname{ttd}$ & $\mathrm{ttd}$ & $\operatorname{ttd}$ & $\operatorname{ttd}$ & $\operatorname{ttd}$ & $\operatorname{ttd}$ & $\operatorname{ttd}$ & $\operatorname{ttd}$ \\
\hline Asam palmitoleat & C16:1 & 3,07 & 7,30 & 7,72 & 7,07 & 7,26 & 7,54 & 7,23 & 7,52 & 7,95 \\
\hline Asam cis-10-Heptadecanoad & $\mathrm{C} 17: 1$ & $\operatorname{ttd}$ & 0,59 & 0,28 & 0,44 & 0,45 & 0,57 & 0,44 & $\operatorname{ttd}$ & 0,2 \\
\hline Asam elaidat & $\mathrm{C} 18: 1 \mathrm{n}-9 \mathrm{t}$ & $\operatorname{ttd}$ & 0,17 & 0,08 & 0,09 & 0,10 & 0,13 & 0,09 & $\operatorname{ttd}$ & 0,06 \\
\hline Asam oleat & $\mathrm{C} 18: 1 \mathrm{n}-9 \mathrm{c}$ & 8,41 & 27,90 & 15,46 & 22,99 & 24,29 & 27,42 & 23,02 & 11,16 & 9,06 \\
\hline Asam cis-11-eicosenoat & C20:1 & 0,68 & 1,44 & 0,92 & 1,20 & 1,29 & 1,47 & 1,18 & 0,65 & 0,76 \\
\hline Asam erukat & C22:1n-9 & 0,02 & 0,26 & 0,16 & Ttd & 0,22 & 0,27 & 0,21 & 0,10 & 0,13 \\
\hline Asam nervonat & $\mathrm{C} 24: 1$ & 0,02 & 0,39 & 0,32 & 0,34 & 0,35 & 0,41 & 0,33 & 0,29 & 0,31 \\
\hline Total MUFA & & 12,26 & 38,11 & 24,98 & 32,18 & 34,01 & 37,87 & 32,54 & 19,75 & 18,5 \\
\hline Asam linoleat & $C 18: 2 n-6 c$ & 5,77 & 0,62 & 0,78 & 0,65 & 0,63 & 0,70 & 0,65 & 0,81 & 0,87 \\
\hline Asam $\Upsilon$-linolenat & $C 18: 3 n-6$ & 0,51 & 0,04 & 0,15 & 0,08 & 0,08 & 0,08 & 0,09 & 0,18 & 0,18 \\
\hline Asam Linolenic & C18:3n-3 & 0,43 & $\mathrm{ttd}$ & $\mathrm{ttd}$ & $\mathrm{ttd}$ & $\mathrm{ttd}$ & $\mathrm{ttd}$ & $\mathrm{ttd}$ & $\mathrm{ttd}$ & $\mathrm{ttd}$ \\
\hline Asam cis-11,14-eicosedienoat & $\mathrm{C} 20: 2$ & 0,04 & 0,28 & 0,18 & 0,23 & 0,23 & 0,29 & 0,22 & 0,13 & 0,15 \\
\hline $\begin{array}{l}\text { Asam cis-8,11,14-eicose- } \\
\text { trienoat }\end{array}$ & $C 20: 3 n-6$ & 0,36 & 0,13 & 0,18 & 0,14 & 0,14 & 0,16 & 0,15 & 0,19 & 0,20 \\
\hline $\begin{array}{l}\text { Asam cis-11,14,17-eicose- } \\
\text { trienoat }\end{array}$ & $C 20: 3 n-3$ & 0,43 & $\mathrm{ttd}$ & $\mathrm{ttd}$ & $\mathrm{ttd}$ & $\mathrm{ttd}$ & $\mathrm{ttd}$ & $\mathrm{ttd}$ & $\mathrm{ttd}$ & $\mathrm{ttd}$ \\
\hline Asam arachidonat & C20:4n-6 & 0,42 & 1,83 & 1,91 & 1,82 & 1,83 & 2,07 & 1,82 & 1,78 & 1,94 \\
\hline $\begin{array}{l}\text { Asam cis-5,8,11,14,17-eicosa- } \\
\text { pentaenoat }\end{array}$ & C20:5n-3 & 12,20 & 1,49 & 7,07 & 3,60 & 3,23 & 2,82 & 3,69 & 8,94 & 8,99 \\
\hline Asam cis-13,16-docosadienoat & $\mathrm{C} 22: 2$ & 0,04 & 0,04 & 0,02 & 0,03 & 0,03 & 0,03 & 0,02 & $\operatorname{ttd}$ & 0,03 \\
\hline $\begin{array}{l}\text { Asam } \\
\text { cis- } 4,7,10,13,16,19 \text {-docosahek- } \\
\text { saenoat }\end{array}$ & C22:6n-3 & 7,39 & 4,64 & 6,96 & 5,67 & 5,60 & 5,73 & 5,60 & 7,24 & 7,59 \\
\hline Total PUFA & & 27,59 & 9,07 & 17,25 & 12,22 & 11,77 & 11,88 & 12,24 & 19,27 & 19,95 \\
\hline Total Asam Lemak Terdeteksi & & 77,79 & 65,14 & 66,49 & 64,69 & 66,16 & 70,94 & 65,03 & 64,04 & 64,56 \\
\hline $\begin{array}{l}\text { Asam Lemak Tidak } \\
\text { Terdeteksi }\end{array}$ & & 22,21 & 34,86 & 33,51 & 35,31 & 33,84 & 29,06 & 34,97 & 35,96 & 35,44 \\
\hline
\end{tabular}


kandungan omega-3 akan semakin tinggi. Profil asam lemak kombinasi minyak ikan sardin dan cucut disajikan pada Tabel 2.

\section{Analisis squalene kombinasi minyak ikan terbaik}

Penggunaan minyak ikan kombinasi 1:4 berdasarkan hasil analisis total oksidasi masih memenuhi standar yang ditetapkan oleh IFOS. Squalene merupakan senyawa target dari uji GC-MS yang terdeteksi pada waktu retensi 22,04 menit. Beberapa senyawa lain terdeteksi yaitu pentadecane, tetracosane, hexadecanoic acid dan oleic acid. Senyawa hasil kombinasi minyak sardin dan cucut 1:4 disajikan pada Tabel 3.

Pentadecane $\left(\mathrm{C}_{15} \mathrm{H}_{32}\right)$ merupakan asam lemak jenuh dengan berat molekul 212,25, terdeteksi dengan waktu retensi 7,12 menit dengan jumlah kelimpahan 13,769\%. Asam lemak pentadecane juga ditemukan pada lemak susu sapi dengan jumlah 1,2\%, asam lemak ini juga terbentuk melalui proses hidrogenasi pada lemak kambing (Smedman et al. 1999).

Tetracosane $\left(\mathrm{C}_{24} \mathrm{H}_{50}\right.$, Lignoceric acid $)$ merupakan asam lemak jenuh rantai panjang dengan berat molekul 422,48 terdeteksi pada waktu retensi 8,43 menit dengan jumlah kelimpahan 19,785\%. Ligneceric acid merupakan hasil samping dari produksi lignin pada tanaman, asam lemak ini juga ditemukan pada lemak kacang tanah dengan jumlah kelimpahan 1,15-1,95\%.

Hexadecanoic acid atau Asam palmitat $\left(\mathrm{C}_{16} \mathrm{H}_{32}\right)$ adalah asam lemak jenuh dengan berat molekul 284,27 terdeteksi pada waktu retensi 10,40 menit. Asam palmitat umumnya banyak ditemukan pada minyak dari famili Palmaceae seperti kelapa 92\%, dan kelapa sawit 50\%. Hasil uji GC-MS pada sampel penelitian mengandung jumlah kelimpahan 7,433\%. Asam palmitat suhu ruang berwujud padat berwarna putih dengan titik leburnya $63,1^{\circ} \mathrm{C}$. Asam palmitat memiliki aktivitas antioksidan dan antimikroba (Graikou et al. 2011).

Asam oleat $\left(\mathrm{C}_{18} \mathrm{H}_{32}\right)$ merupakan senyawa dengan berat molekul 310,28 terdeteksi pada waktu retensi 11,81 menit. Asam oleat atau biasa dikenal dengan nama omega-9 yang merupakan jenis asam lemak MUFA. Hasil uji pada GC-MS sampel penelitian mengandung jumlah kelimpahan omega-9 15,852\%. Suseno et al. (2010) menjelaskan bahwa Omega-9 memiliki manfaat yang sangat besar bagi kesehatan yaitu membantu menurunkan kolesterol jahat, menurunkan trigliserida dalam darah, meningkatkan kolesterol HDL (high density lipoprotein). Juniaty dan Balittri (2012) menyatakan bahwa omega-6 dalam bentuk tunggal memiliki sifat negatif karena berkaitan dengan peningkatan produksi eikosanoid (stimulant pertumbuhan tumor pada binatang percobaan), namun dengan adanya omega-9 dalam proporsi yang sesuai memiliki potensi memblokir produksi senyawa eikosanoid tersebut, sehingga peran omega-9 dapat mencegah stimulasi negatif omega-6.

Squalene $\left(\mathrm{C}_{30} \mathrm{H}_{50}\right)$ adalah senyawa dengan berat molekul 410,39 terdeteksi pada waktu retensi 22,04 menit. Squalene merupakan senyawa hidrokarbon rantai panjang tidak jenuh, terdapat pada minyak hati ikan cucut, terutama keluarga Squalidae, minyak ikan cod, minyak zaitun, minyak kelapa, minyak gandum, minyak bayam dan minyak dedak padi (Nunez 2007). Hasil uji GC-MS menunjukkan bahwa kelimpahan

Tabel 3 Senyawa hasil perbandingan puncak-puncak spektrum massa kombinasi minyak sardin dan cucut (1:4)

\begin{tabular}{lccccc}
\hline \multicolumn{1}{c}{ Nama senyawa } & $\begin{array}{c}\text { Rumus } \\
\text { molekul }\end{array}$ & $\begin{array}{c}\text { Berat } \\
\text { molekul }\end{array}$ & $\begin{array}{c}\text { Waktu } \\
\text { Retensi }\end{array}$ & $\begin{array}{c}\text { Kelimpahan } \\
(\%)\end{array}$ & $\begin{array}{c}\text { Indeks kemiri- } \\
\text { pan (\%) }\end{array}$ \\
\hline Pentadecane & $\mathrm{C}_{15} \mathrm{H}_{32}$ & 212,25 & 7,12 & 13,769 & 97 \\
Tetracosane & $\mathrm{C}_{24} \mathrm{H}_{50}$ & 422,48 & 8,43 & 19,785 & 92 \\
Hexadecanoic acid & $\mathrm{C}_{16} \mathrm{H}_{32}$ & 284,27 & 10,40 & 7,433 & 98 \\
Oleic acid & $\mathrm{C}_{18} \mathrm{H}_{32}$ & 310,28 & 11,81 & 15,852 & 96 \\
Squalene & $\mathrm{C}_{30} \mathrm{H}_{50}$ & 410,39 & 22,04 & 43,169 & 99 \\
\hline
\end{tabular}


Squalene tertinggi dari kelima senyawa yang terdeteksi yaitu 43,169\%. Undjung (2005) menyatakan bahwa minyak ikan cucut (Centrophorus atromarginatus) yang ditangkap di perairan pantai pagatan Propinsi Kalimantan Tengah mengandung Squalene mencapai $83 \%$. Catchpole et al. (1997) menyatakan bahwa kandungan Squalene pada hati ikan cucut mencapai 50\%. Kamimura et al. (1992) menyatakan Squalene dapat mengurangi toksisitas obat yang dikonsumsi.

\section{KESIMPULAN}

Kombinasiminyakikan terbaik ditemukan pada rasio 1:4 (sardin:cucut) berdasarkan parameter total oksidasi yang memenuhi standar IFOS dengan kandungan omega-3 yaitu 8,55\% dan Squalene yaitu 43,16\%. Minyak sardin jika banyak ditambahkan pada rasio kombinasi menghasilkan kandungan omega-3 yang semakin tinggi.

\section{DAFTAR PUSTAKA}

Aidos I, Jacobsen C, Jensen B, Luten JB, van der Padt A, Boom RM. 2002. Volatile oxidation products formed in crude herring oil under accelerated oxidation conditions. Journal Lipid Sci Tech. 4:148161.

Aidos I, Schelvus-Smit R, Veldnan MB, Luten J, Padt AVD, Boom RM. 2003. Chemical and sensory evaluation of crude oil extracted from Herring by-products from different processing operations. Journal Agric Food Chem. 51(7):1897-1903.

[AOAC] Association of Official Analytical Chemist. 2005. Official Method of Analysis of The Association of Official Analytical of Chemist 18th edition edition. Arlington. Virginia: AOAC Pr.

[AOCS] American Oil Chemists Society. 1995. Official Methods and Recommended Practices of the American Oil Chemists Society, 5th edition: AOCS Pr.

[AOCS] American Oil Chemists Society. 1998. Official Methods and Recommended Practices of the American Oil Chemists Society, 5th edition: AOCS Pr.

Baken, Dilli, Fettah, Kabatas. 2014. The influence of fish-oil lipid emulsions on retinopathy of prematurity in very low birth weight infants: A randomized controlled tria. Journal Early Human Development. 90:27-31.

Bimbo AP. 1998. Guidelines for characterizing food-grade fish oil (9 $9^{\text {th }}$-ed) 473-483. Hertfordshire: Inform.

Catchpole O, Kamp P, Grey. 1997. Extraction of squalene from shark liver oil in a packed column using supercritical carbon dioxide. Journal Chemistry. 36(10):43184324

Dewita, Syahrul, Desmelati, Lukman S. 2015. Inovasi bubur instan dan cookies berbasis konsentrat protein ikan patin yang difortifikasi minyak sawit merah dan minyak patin terenkapsulasi. Jurnal Pengolahan Hasil Perikanan Indonesia. 18(3):315-320

Gunawan, Triatmo MMA, Rahayu A. 2003. Analisis pangan: penentuan angka peroksida dan asam lemak bebas pada minyak kedelai dengan variasi menggoreng. Jurnal Kimia Analitik. 6(3):1-6.

Graikou K, Suzanne K, Nektarios A, George S, Niki C, Efstathios G, Ionna C. 2011. Chemical analysis of greek pollen-antioxidant, antimicrobial and proteasome activation properties. Journal Chemistry. 33(5):1-9.

Gracia N, Aguilar P, Cordova, Suarez, Balanos. 2000. Lipid composition of liver oil of shark species from the caribbean and gulf of california Waters. Journal of Food Composotions And Analysis. 13:791-798.

Hernandez E, Kamal-Eldin A. 2013. Processing and Nutrition of Fats and Oils. Amerika Serikat: John Wiley \& Sons, Ltd. [IFOS] International Fish Oils Standard. 2014. Fish Oil Purity Standards.

Ilza M, Siregar YI. 2015. Sosialisasi penambahan minyak perut ikan jambal siam an minyak ikan kerapu pada bubur bayi untuk memenuhi standar omega 3 dan omega 6. Jurnal Pengolahan Hasil Perikanan Indonesia. 18(3): 262-275.

Juniaty T, Balittri. 2012. Kenari (Canarium indicium) sebagai sumber omega-3, omega-6 dan omega-9. Warta Penelitian dan Pengembangan Tanaman Industri. 
[Internet];[diunduh 2016 Sep 23].http:// www.perkebunan.litbang.pertanian. do.id.

Kamimura H, Koga N, Oguri K, Yoshimura $\mathrm{H}$ 1992. Enhanced elimination of theophylline, phenobarbital and strychnine from the bodies of rats and mice by squalene treatment. Journal Pharmacobiody. 15:215-221.

Ketaren S. 2012. Minyak dan Lemak Pangan. Jakarta (ID): UI Press.

Kelly G. 1999. Squlene and its potential clinical uses. Alternative Medicine Review. 4(1):29-36.

Kohno Y, Egawa Y, Itoh S. 1995. Kinetic Study of quenching reaction of singlet oxygen and scavenging reaction of free radical by squalene in n-butanol. Journal Biochim Biophys Acta. 1256:52-56.

Loef M, Walach H. 2013. The omega-6/ omega-3 ratio and dementia or cognitive decline: A Systematic review on human studies and biological evidence. Journal of Nutrition in Gerontology and Geriatrics. 32(1):1-23.

Nunez GC. 2007. Quality and Stability of Cuban Shark Liver Oil: Comparasion with Icelandic Cod Liver Oil. UNU. Fisheries Training Programme.

Perrin JL. 1996. Determination of alteration. In: Karleskind A, Wolff JP. (Eds.) Oils and Fats, Manual vol. 2. Paris (Fr):Lavoisier Pr.

Schuchardt JP, Huss M, Stauss-Grabo M, Hahn A. 2010. Significance of longchain polyunsaturated fatty acids (PUFA) for the development and behaviour of children. Jounal Nutrition. 169(2): 149164.

Suseno SH, Nurjanah, Jacoeb AM, Saraswati. 2013a. Purification of Sardinlla sp., Oil: centrifugation and bentonite adsorbent. Journal of Food Science and Technology. 6(1):60-67.
Suseno SH, Nurjanah, Faradiba. 2013 ${ }^{\mathrm{b}}$. Profil asam lemak dan kestabilan produk formulasi minyak dan habbatussauda. Jurnal Pengolahan Hasil Perikanan Indonesia. 16(2):142-149.

Suseno SH, Tajul, Nadia, Hamida, Asti, Ali. 2010. Proximate, fatty acid and mineral composition of selected deep sea fish species from Southern Java Ocean and Western Sumatra Ocean Indonesia. International Food Research Journal. 17:905-914.

Suseno SH, Jacoeb AM, Bija, Fitriana N, Ruspatti NP. 2016. The effect of citric acid and sodium chloride $(\mathrm{NaCl})$ to quality ofsardine oil (Sardinella sp.). Journal Biotechnol. 13(3):181-186.

Suseno SH, Syari C, Zakiyah ER, Jakoeb AM, Izaki AP, Saraswati, Hayati. 2014. Low temperature extraction and quality of oil from spotted Sardinella (Amblygaster sirm) and Goldstrip Sardinella (Sardinella gibbosa). Journal of Fish and Marine Sciences. 6 (5):435-440.

Smedman AE, Gustafsson IB, Berglund LG, Vessby BO (1999). Pentadecanoic acid in serum as a marker for intake of milk fat: relations between intake of milk fat and metabolic risk factors. Journal Clinical Nutrition. 69(1):9-22.

Undjung D. 2005. Contious production of pure squalene by using column chromatography. Journal Chemistry. 5(3):251-254.

Watson CA. 1994. Official and standardized methods of analysis (Third Ed.). Cambridge: The Royal Society of Chemistry.

Wetherbe B, Nichols P. 2000. Lipid composition of the liver oil of deep-sea sharks from the Chatham Rise, New Zealand. Journal Comparative Biochemistry and Physiology. 125:511-521. 